The Orient Within 



\section{THE ORIENT WITHIN}

Muslim Minorities and the

Negotiation of Nationhood in

Modern Bulgaria

Mary Neuburger

Cornell University Press 
Copyright $@ 2004$ by Cornell University

All rights reserved. Except for brief quotations in a review, this book, or parts thereof, must not be reproduced in any form without permission in writing from the publisher. For information, address Cornell University Press, Sage House, 5 I 2 East State Street, Ithaca, New York 14850.

First published 2004 by Cornell University Press

First printing, Cornell Paperbacks, 2011

Printed in the United States of America

\section{Library of Congress Cataloging-in-Publication Data}

Neuberger, Mary, I966-

The Orient within : Muslim minorities and the negotiation of nationhood in modern Bulgaria / Mary Neuberger.- Ist ed.

p. cm.

Includes bibliographical references and index.

ISBN 978-0-8014-7720-1

I. Muslims-Bulgaria. 2. Nationalism-Bulgaria. 3.

Bulgaria-Politics and government-r990- I. Title.

DR64.2.M8 $\mathrm{N}_{4} 82004$

305.6' $97^{\prime} 09499$-dc22

2003020155

Cornell University Press strives to use environmentally responsible suppliers and materials to the fullest extent possible in the publishing of its books. Such materials include vegetable-based, low-VOC inks and acid-free papers that are recycled, totally chlorine-free, or partly composed of nonwood fibers. For further information, visit our website at www.cornellpress.cornell.edu.

$\begin{array}{lllllllllll}\text { Cloth printing } & \text { I } & 9 & 8 & 7 & 6 & 5 & 4 & 3 & 2 & \text { I }\end{array}$ 


\section{To Donald}

For your patience and understanding during my many trips to the Balkans and innumerable hours at the computer. 
